July 2006

\title{
Rwanda and Darfur: A Comparative Analysis
}

Scott Straus

Follow this and additional works at: https://digitalcommons.usf.edu/gsp

\section{Recommended Citation}

Straus, Scott (2006) "Rwanda and Darfur: A Comparative Analysis," Genocide Studies and Prevention: An International Journal: Vol. 1: Iss. 1: Article 8.

Available at: https://digitalcommons.usf.edu/gsp/vol1/iss1/8

This Articles is brought to you for free and open access by the Open Access Journals at Digital Commons @ University of South Florida. It has been accepted for inclusion in Genocide Studies and Prevention: An International Journal by an authorized editor of Digital Commons @ University of South Florida. For more information, please contact digitalcommons@usf.edu. 


\title{
Rwanda and Darfur: A Comparative Analysis
}

\author{
Scott Straus \\ Department of Political Science, University of Wisconsin, Madison
}

\begin{abstract}
The article presents a comparative analysis of genocide in Rwanda and Darfur. The first half of the article examines the patterns and origins of violence in both cases and uses the comparison to generate some theoretical inferences about the causes of genocide. The analysis finds that both cases demonstrate a similar character of violence but that in Rwanda the violence was more intense, more exterminatory, and more participatory than in Darfur. Both episodes took place in the midst of civil war, in periods of political transition, in countries with histories of ethnic nationalism, and in areas where the conflicting ethnic populations lived in relative proximity. However, in Rwanda the state is more compact, centralized, and effective, which may explain the variation in intensity. The second half of the article focuses on the international response to genocide in both cases. After Rwanda, observers emphasized the importance of using the label "genocide" and creating domestic constituencies. Darfur showed that both strategies are insufficient. In response to Darfur, US officials declared "genocide" to be occurring, and there emerged a politically diverse civil-society coalition to lobby the administration. Yet the net outcome for both cases, in terms of the absence of an effective policy to halt genocide, was the same. The article argues that focusing too intently on a "genocide" determination may be counterproductive, that international politics matter yet mobilization on Darfur outside of North America was weak, and that protocols for the use of force to prevent genocide should be clarified.
\end{abstract}

\section{Introduction}

Since the Darfur crisis began in 2003, the Rwandan genocide of 1994 has been a frequent comparative point of reference. Some commentators have called the violence in western Sudan "another Rwanda," others a "slow-motion" Rwanda. Most often, the comparison has had two primary connotations. The first concerned the violence itself. Genocide was happening again in Darfur, and hence Darfur was like Rwanda. The second connotation concerned the international response to the violence. As in Rwanda, the international community was not acting to stop genocide, and hence Darfur was like Rwanda.

Both comparative claims are accurate, as far as they go. However, the claims also deserve closer scrutiny. To what degree are the patterns of violence in Rwanda and Darfur similar? To what degree are they different? From an international perspective, in what ways is the response to Darfur similar to and different from what happened in Rwanda? Answers to these questions have inherent epistemological value, but they also have theoretical and practical import. From a theoretical perspective, what do the commonalities and differences between the two cases suggest about why genocide happens? From a practical perspective, what do the international reactions to both cases indicate about the effectiveness (or lack thereof) of particular prevention strategies? 
This article approaches Darfur and Rwanda with these comparative questions and objectives in mind. The central purpose is to analyze similarities and differences between the two cases in order to generate theoretical and practical inferences. The article does not make normative claims about differences between the cases. I argue below that violence in Rwanda was more intense and more exterminatory than it has been in Darfur. The point is not that Rwanda's violence was worse than Darfur's, nor is it that Rwanda's victims suffered more than Darfur's victims. From a survivor's perspective, violence is violence; the loss of a family member is the loss of a family member. But from a comparative analytical perspective, empirical differences (and similarities) are important to note because they can generate insights about the causal dynamics of mass violence. This article focuses only on two cases, and hence the theoretical inferences have limited generalizability. Nonetheless, because the analogy between Rwanda and Darfur is often made and because comparative analysis can yield valuable insights, I pursue it here.

Broadly, the article is divided into two sections, each with several subsections. In the first main section, I discuss the dynamics of genocide in both cases, addressing the primary patterns of violence in Darfur and in Rwanda as well as common causal factors in both cases. I then make some theoretical observations based on the analysis, noting both similarities and differences. In the second main section, I discuss the international response to genocide in both cases. Here I focus on three main areas: the debate over whether to use the label "genocide" in both cases; the formation (or lack thereof) of a domestic constituency in the United States calling for prevention; and, finally, international obstacles to prevention.

\section{Dynamics of Genocide in Darfur and Rwanda}

\section{Patterns of Violence}

One nexus of comparison between the two cases concerns intensity of violence, in particular the rate of killing (that is, the number of deaths over time). As of this writing in April 2006, large-scale attacks on civilian populations in Darfur have been continuing for three years, with some variation over time. Judging from existing data, it appears that attacks surged in late 2003 and early 2004, declining in early 2005. The violence also appears concentrated in some parts of Darfur but not in others. ${ }^{1}$ The number of deaths in this period is the subject of some controversy. Some estimate between 63,000 and 140,000 violence-related civilian deaths, while others put the number at 400,000 (Darfur's population before the violence began was about 6.5 million). The low estimate comes from a 2005 US State Department report. The high estimate comes from a 2005 report issued by the Coalition for International Justice (CIJ); the report was based on research conducted in conjunction with other scholars. ${ }^{2}$ The primary reasons for the divergent estimates in these reports relate to assumptions about the constancy of violence over time, about the distribution of violence across regions in Darfur, and about whether existing survey data are representative.

By contrast, the Rwandan genocide took place during the 100-day period from 6 April to 17 July 1994. There was variation in when violence started in different regions, but ultimately genocidal violence occurred in almost every part of the country under government control. Most murders took place during the first five weeks of the genocide. Detailed data from one region (Kibuye Prefecture) indicate that two weeks into the genocide nearly $80 \%$ of all murders had already taken place. ${ }^{3}$ Estimates of the number killed in Rwanda range from 500,000 to one million. The difference in the estimates depends principally on how many Tutsis are said to have lived in Rwanda 
before the genocide. Thus, even a low estimate of the number killed yields a very high ratio of the number of Tutsis killed as a percentage of the pre-existing Tutsi population. For example, in one of the best studies of the genocide, Alison Des Forges gives a low estimate of 500,000 Tutsis killed, but that sum equals $75 \%$ of all resident Tutsis in Rwanda before the genocide. ${ }^{4}$

Similar ratio estimates for Darfur do not yet exist. In other words, it is not clear exactly how many black African Darfuris have been killed as a percentage of the preexisting black African population. That said, the ratio is likely to be smaller. As of this writing, there are considerably more black Africans in Darfur who have been displaced than black Africans who have been killed through direct or indirect means. This is true even if, to date, the violence in Darfur has lasted ten times longer than it did in Rwanda. In short, the violence in Rwanda was more intense than that in Darfur-it was faster and more murderous.

The modes of violence follow the same logic. In Darfur, forced displacement, destruction of villages, destruction of the means of survival, killing of men, and mass rape are the principal modes of violence. ${ }^{5}$ Of these, forced destruction and destruction of villages are the primary modes of violence and the primary source of mortality in Darfur. Lacking access to food, clean water, shelter, and medical care, many displaced Darfuris have died because of disease and malnutrition. According to the CIJ report, direct killing accounts for about $35 \%$ of all deaths. ${ }^{6}$ Again using the CIJ estimate, the number displaced in Darfur is about seventeen times the number directly killed. (As of this writing, an estimated 2.4 million people have been forced from their homes and are living as refugees in Chad or internally displaced persons [IDPs] within Sudan.) In short, forced displacement-and the related consequences of disease and malnutrition-is the primary source of death, and this, as we shall see, stands in contrast to Rwanda.

The violence in Darfur has primarily been against black Africans. Ethnicity in Darfur is complex, and I discuss it below. But perpetrators often characterize the targets of their violence as "blacks," "Nubas," or "Zurgas." Darfur is home to three large black African tribes-the Fur, the Massaleit, and the Zaghawa-and perpetrators appear to attack anyone who belongs to these groups. Various investigations are consistent on this point: the violence is deliberately waged against Darfur's black African populations. ${ }^{7}$

The perpetrators in Darfur are mainly government soldiers and militias. The Sudanese Air Force has also participated in attacks by bombing villages before soldiers and militias launch ground attacks. There is considerable evidence that the militia, army, and air force act in a coordinated fashion. Soldiers and militias sleep in the same camps; the government also has supplied the militias, who most frequently go by the name "janjaweed" or "janjiwid." After studying the matter in some depth, U.S. officials at the State Department concluded that there was close coordination between Sudanese armed forces and the militias. ${ }^{9}$ Militia leaders also readily admit that they are acting on government orders. ${ }^{10}$

How does all this compare with the situation in Rwanda? In general, the character of violence was similar - in both cases, the violence was directed by the state, targeted at a particular ethnic population, and intended to destroy that ethnic population in substantial part. If the standard for determining "genocide" is the legal one established by the International Criminal Tribunal for the former Yugoslavia (ICTY), both are cases of genocide. That said, direct killing was the primary mode of violence in Rwanda. Where Tutsis were found, they were most often killed; there was relatively 
little forced displacement. The violence in Rwanda also happened countrywide (rather than in one region), and it occurred over a much shorter period of time. In Rwanda, perpetrators additionally attacked and killed leading Hutu opposition politicians and Hutus who openly refused to participate in the genocide. Such intra-ethnic violence appears to be less present in Darfur.

Rwanda, like Darfur, experienced significant levels of sexual violence. Some authors estimate that 250,000 to 500,000 rapes were perpetrated during the Rwandan genocide. However, that number is a somewhat imprecise estimate: it is based on the number of pregnancies from rape reported after the genocide. ${ }^{11}$ Sexual violence is so commonly reported in Darfur that it may be more prevalent in that case than in Rwanda. ${ }^{12}$ More research on the question is needed. As in Darfur, destruction and looting of property were features of the violence in Rwanda. Many homes of Tutsis and dissident Hutus were destroyed, both before and after Tutsis were killed; Tutsi homes were also occupied during and after the genocide. But in Rwanda, unlike Darfur, few villages (or other administrative units) were completely destroyed. Prior to the genocide in Rwanda, Hutus and Tutsis in Rwanda lived side by side throughout the country; there were almost no administrative units where only Tutsis lived. As a consequence, the destruction of homes was selective, while in Darfur entire villages were routinely destroyed.

Concerning the perpetrators, as in Darfur, Rwanda's génocidaires included soldiers, police, and militia. In many instances, Rwandan soldiers and militia were instrumental in the largest massacres at church sites, schools, and other locations where large numbers of Tutsis had gathered. However, one difference between the two cases concerns civilian mobilization. In Rwanda, state and military officials deliberately sought-and sometimes required-the participation of large numbers of Hutu civilian men who, until that point, had had no prior history of violence. The result was that even though soldiers and militias often were involved in killings of the greatest magnitude, ordinary civilian men were probably more numerous in the perpetration of the genocide than were soldiers and militarily trained militias. Ordinary civilian participation in Darfur seems less present.

The violence in Darfur and that in Rwanda are both examples of state-directed, large-scale violence against civilian populations defined in ethnic terms. Both cases resulted in massive loss of life (in Darfur, the loss of life continues); both have significant levels of sexual violence; and both involve soldiers and militias. The main differences concern intensity. The violence in Rwanda was faster, more exterminatory, and more participatory-that is, it involved the participation of far larger numbers of civilians - than in Darfur. In short, these cases are of the same genre. They are both cases of genocide-if the standard for genocide is the United Nations Convention on the Prevention and Punishment of the Crime of Genocide (UNCG). However, the two cases are not identical.

\section{Origins of Violence in Darfur}

The roots of violence in Darfur and Rwanda are complex, but the two cases have a number of commonalities that, themselves, have theoretical implications. Darfur's violence has intersecting local, national, and regional lineages, some stretching back several decades.

The first principal long-term lineage of the violence in Darfur relates to local resource conflicts and local ethnic conflict. Identity is not straightforward in Darfur (nor in Rwanda; more on the latter below). The region is home to more than three 
dozen ethnic and sub-ethnic groupings, but within those groupings there are two main intersecting cleavages. The first is between sedentary farmers and semi-nomadic herders; the other is between black Africans and Arabs. The two cleavages usually overlap-that is, Arab families often engage in semi-nomadic pastoralism, while black African families often engage in sedentary agriculture. That said, many Arab families grow crops, and many black Africans raise livestock. Both groups also participate in non-farming and non-husbandry professions. Moreover, "black African" and "Arab" are somewhat misnomers, in that the two populations, partly because of intermarriage, have similar physical appearances, and everyone is technically African. The groups are also uniformly Muslim. Nonetheless, the Arab and black African social categories exist and are meaningful to Darfuris.

In recent years, several factors have increased tension between Arabs and black Africans in the region. Starting in the 1980s, in particular, drought, famine, and desertification increased competition for dwindling resources, especially water and grazing areas. Herders encroached on agriculturalists' lands, leading to mutual arming. Some nomadic herders began purchasing weapons to protect their livestock and to increase the roaming range of their animals, while some farmers bought arms to protect their land. ${ }^{13}$

National policies and politics increased the local tensions. Northern Arabs have dominated the Sudanese state since independence. That domination is the source of a long-running civil war between north and south in Sudan (more below). As conflict in Darfur escalated, government leaders in the capital, Khartoum, backed local Arabs. Northern leaders supplied weapons to local Arabs and promoted Arabs in local government positions, thereby increasing Arab power and leverage in the region and marginalizing black Africans. ${ }^{14}$

There was also a regional dynamic, involving a conflict between Chad and Libya. In order to unseat a government in Chad, Libyan leader Muammar al-Qaddafi funded Chadian rebels based in Darfur. The presence of Chadian rebels in Darfur in the 1970s and 1980s had two principal effects. The first was that it led to the availability of cheap weapons, which facilitated the arming of both local Arabs and local Africans. The second was that the Chadians and Libyans, in particular, introduced and promoted Arab supremacist ideology in Darfur. Libya is also the source of a Darfuri Arab supremacist organization called the "Arab Gathering" or "Arab Union."15

The sequencing of these local, national, and regional influences is not yet clear. But this brief discussion highlights two important points. First, conflict between Arabs and black Africans in Darfur was real and salient prior to the eruption of mass violence in 2003; the conflict intensified in the 1980s and continued through the 1990s. Second, the ethnic divisions have a history-the conflict is not one of "ancient hatreds" but, rather, one whereby particular conditions and influences increased the salience of ethnicity and intensified tension between groups. As some Darfuris claim, "Conflict defines origins"- that is, identity-based cleavages are as much the consequences as the causes of violence. ${ }^{16}$

There is another, more proximate lineage to the violence in Darfur-namely, the gradual ending of the civil war between the northern, Arab-dominated government, on the one hand, and Christian and animist black southerners, on the other. Various iterations of the North-South war have afflicted Sudan for all but ten years since the country's independence from Britain in 1956. Since 1983, alone, the war in the south has cost an estimated two million lives. Beginning in 2001, however, the government and the main southern rebel movement, the Sudan People's Liberation Movement 
(SPLM), entered into comprehensive peace negotiations. After numerous rounds of talks, the two sides reached agreement; in January 2005, government and rebel delegations officially ended the war, to much international acclaim. However, Darfur was not represented in the negotiations. Black Africans in Darfur, who had felt marginalized because of government-supported discrimination and who had conflicted with local Arabs in the past, worried about their future in post-war Sudan. Those various concerns led two black African groups to launch an armed rebellion against the Sudanese state in $2003 .^{17}$

Civil war is the other principal proximate origin of genocide in Darfur. After officially launching the rebellion, rebels in Darfur won a series of battles against government forces. ${ }^{18}$ The government responded by arming and supporting Arab militias; together, they targeted the rebels and the rebels' presumed supporters: "black Africans" became the enemy. The result is what we have seen: coordinated militarymilitia attacks on the black African population of Darfur. The goal-according to a document cited by Julie Flint and Alex de Waal-became to "change the demography of Darfur and empty it of African tribes."19

\section{Origins of Violence in Rwanda}

The roots of violence in Rwanda have much in common with those in Darfur. In Rwanda, ethnicity was a salient cleavage that pre-existed the mass violence, although, as in Darfur, ethnic difference in and of itself also did not cause violence during most periods. In Rwanda, there are two principal ethnic groupings, Hutu and Tutsi (though other identities, including regional, class, and clan, also matter). Hutus and Tutsis do not fit a standard model of deeply divided ethnic groups. The two groups speak the same language, practice the same religions, live in the same regions, and share numerous other attributes. Hutus and Tutsis in Rwanda also intermarried frequently, at least before the genocide.

That said, Rwanda has a pronounced history of political ideologies based on ethnicity and race. That history is long (and beyond the terms of this article), but the colonial and independence periods are critical to understand. The colonial experience racialized and hardened previously more fluid and more complex identities. ${ }^{20}$ The exact precolonial nature of the Hutu and Tutsi categories is unclear, but they related to status, economic activity, and relationship to the monarchy. Europeans, however, saw Hutus and Tutsis as races, and the colonialists favored the Tutsis, whom they viewed as a superior race. In the colonial system, Tutsis were systematically favored, and an elaborate racial discourse developed to support Tutsi power. That changed at independence, when Hutu counter-elites argued that Hutus should rule because they were the majority (constituting about $85 \%$ of the population). The Belgians ultimately backed that position, giving birth to the "Hutu Revolution," whereby Tutsis were violently ousted from power, the monarchy was abolished, and Hutus came to dominate the newly independent Rwanda. An ideology of Hutu rule remained a part of Rwandan political culture, particularly among elites, even if, on a day-to-day basis, ordinary Hutus and Tutsis interacted without hostility at most times from independence through the 1990s.

Like Darfur's, Rwanda's genocide also had proximate roots. In particular, the mass violence in Rwanda occurred during a civil war. Rwanda experienced two primary phases of war. Between 1990 and 1993, Tutsi-dominated rebels fought Hutu-led government forces. In August 1993, the two sides signed a peace agreement, but on 6 April 1994, the Rwandan president was assassinated, which triggered a new round of 
the civil war. The genocide occurred during the second phase of the civil war, and the logic of war was central to the rationale for killing Tutsi civilians. Tutsis-all Tutsiswere labeled rebel accomplices and killed as wartime "enemies."

Like Darfur's, Rwanda's violence occurred during a period of political upheaval. In Sudan, the sources of political change and instability were the peace negotiations with the southern rebels and factionalism within the ruling party. ${ }^{21}$ In Rwanda, the sources of change and instability were the civil war, the peace negotiations, and the transition from a single-party to a multi-party state. In Rwanda, the civil war displaced tens of thousands; the 1993 peace agreement called for a major restructuring of the army; and multi-partyism undermined and threatened the power of ruling elites (as did the civil war).

In short, the two episodes have some causal factors in common. In particular, the violence took place in the midst of a war between governments and rebel groups that, respectively, had strong ethnic identifications. In both episodes, the violence happened during a period of political turmoil and change. And in both countries there pre-existed political ideologies based on ethnicity and a history of ethnic identification. The point is not that there was "ancient ethnic hatred" in both places but that ethnic classifications and ethnic political ideologies were meaningful and resonant prior to the violence.

But, as previously mentioned, violence in Rwanda was more intense and more exterminatory than that in Darfur. One reason for this may relate to the character of state power. In contrast to Sudan, Rwanda is a compact, densely populated country with centralized and locally intensive state institutions. The Rwandan state also has a long history of forced labor, a history that dates back to the precolonial period (and extends into the colonial and postcolonial periods). The geography is one of rolling, farmed or grazed hills-making the rural population vulnerable to local surveillance. By contrast, Sudan is a vast, sparsely populated state with a more decentralized governing structure. Darfur has, moreover, experienced political and administrative neglect since well before independence. ${ }^{22}$ The result is that Sudan's state capacity for local control and civilian mobilization is less than Rwanda's. The patterns of violence follow: in Darfur, the violence is slower, less intense, and less participatory than in Rwanda. The character of state institutions and power in both places may, in part, explain this variation.

\section{Theoretical Implications}

What, if any, are the theoretical implications of this brief comparative analysis? The analysis is not a definitive test of different theories of genocide. Nonetheless, the comparison does yield some theoretical inferences, and it does provide some evidence to support (and detract from) different existing explanations of mass ethnic violence.

Viewed together, Darfur and Rwanda provide evidence to support the hypothesis that genocide happens in periods of political upheaval and transition. ${ }^{23}$ By contrast, the evidence detracts from theories such as those of Rudolph Rummel, who claims that absolute power is a precondition for genocide. ${ }^{24}$ In both Rwanda and Sudan, national elites chose radical, genocidal measures as their power eroded or threatened to erode. In both cases, the sources of the erosion were sharp divisions within ruling coalitions, looming elections combined with limited public support for ruling parties, peace negotiations that would have led to significant change, and civil war. It was in this context of fractured and fracturing power-not one of absolute, uncontested dictatorship-that national elites, who still dominated key institutions such as the military, chose extreme strategies to maintain their control and dominance. 
Darfur and Rwanda also provide evidence to support the hypothesis that war and genocide are causally related. In both cases, genocide happened during periods of intense civil war. Perpetrators in both cases linked the logic of war to the logic of mass violence; that is, they justified their tactics as counter-insurgency and self-defense. Moreover, in both cases the strategy of mass violence occurred as government forces were on the defensive. In Rwanda, Hutu hardliners committed genocide as they were losing ground to rebels; in Darfur, hardliners advocated mass violence after the rebels won a series of victories. That war was a central causal factor in the Rwandan genocide is a central conclusion of my own research. ${ }^{25}$ Scholars of genocide increasingly point to the importance of war. ${ }^{26}$ Darfur provides further evidence to confirm the claim. Intense, defensive episodes of civil war combined with political upheaval and fractured power appear to drive extreme violent measures on the part of ruling elites.

Scholars of genocide have consistently highlighted a relationship between ideological notions of perfection, utopia, and purity, on the one hand, and mass violence, on the other. ${ }^{27}$ The idea that genocide is rooted in top-down ideological attempts to create utopias has clear application to the Nazi case, as well as to Cambodia under the Khmer Rouge. However, Darfur and Rwanda do not lend clear support to the hypothesis. In both cases, ideologies of ethnic nationalism and exclusive ethnic rule pre-existed the violence (see below), but in neither case do there appear to be the kinds of messianic, metaphysical, and fantastical notions associated with creating perfection. In Darfur and Rwanda, war, fractured power, political upheaval, and the associated material fears drove the radicalization of national elites more than utopian, revolutionary visions of society did.

Both Rwanda and Darfur indicate the importance of ethnic nationalism, but in surprising ways. In Rwanda, an ideology of majoritarian Hutu nationalism underpinned each post-independence government before the genocide. In Sudan, Arab nationalism has been a consistent feature of Khartoum governments since independence. ${ }^{28}$ At the same time, however, in both cases the mass violence happened as-or after-ruling elites had entered into peace negotiations with formerly excluded groups. In Rwanda, just prior to the genocide, the Habyarimana government had signed a peace agreement (the Arusha Accords) with Tutsi rebels; in Sudan, as Darfur broke, the al-Bashir government was in the process of finalizing a peace deal with southern rebels. Many argue that Rwanda's peace deal led to extremism; the compromise with Tutsi rebels angered nationalists, who then turned to irregular measures to keep power. ${ }^{29}$ It is unclear whether something similar happened in Sudan. But genocide did not happen during a period of official insistence on exclusive ethnic nationalism; rather, in both cases, the mass violence happened after or during peace negotiations with previously excluded "others." None of this detracts from the claim that ethnic nationalism is an ideological foundation for genocide. ${ }^{30}$ Empirically, however, the evidence from both cases suggests that the timing of mass violence relates to when the ethnic exclusivity of a ruling coalition is ending or threatens to end.

Rwanda and Darfur also provide some evidence about the importance of ethnicity to genocide, but, again, in surprising ways. Some theories suggest that deep divisions, hatred, and widespread prejudice are essential conditions of large-scale violence and genocide. ${ }^{31}$ Ethnicity was salient before the mass violence in both Darfur and Rwanda. However, what is unusual about these two cases is that the communities in question lived in relative proximity, and thus both Darfur and Rwanda suggest that ethnic proximity may matter more than ethnic distance in producing mass violence. In Rwanda, Hutus and Tutsis are interconnected populations. Not only do Hutus and 
Tutsis speak the same language, practice the same religion, and so forth, they also, before the genocide, lived next door to one another throughout the country and intermarried. In Sudan, much of the country is deeply split between northern Arab Muslims and southern black Christians and animists. But Darfur does not fit that mold. As noted above, Darfuris are uniformly Muslim; Arabs and Africans live in relative proximity (at least compared to Arabs and black Africans in other parts of the country); and there was some intermarriage between the groups.

Why ethnic proximity might lead to mass violence is less clear. It may be that proximity increases security fears in wartime. It may be that opportunity for violence is greater: if ethnic groups live in distant parts of the country, then mass killing becomes more difficult. It may be that proximity increases information, which, in turn, facilitates killing. These (and other) hypotheses deserve more research. The argument does not apply to all cases of genocide; it would appear not to work, for example, for the Armenian genocide (though it does appear to work for what took place in Bosnia in the 1990s). The point is only that the evidence from Darfur and Rwanda indicates that mass violence happens among relatively proximate ethnic communities, and this may offer some clue as to why violence happens on this scale.

The various claims in this section are neither comprehensive nor conclusive. Objections may be raised to each of the arguments. Every war does not lead to genocide, every period of political instability does not lead to extremism, and there are many instances of ethnic proximity in which peace holds over time. Each point needs theoretical refinement. Nonetheless, the comparison does reveal some counterintuitive patterns, and it does generate theoretical inferences, which, in turn, point the way for further comparative research.

\section{International Responses}

Darfur and Rwanda are instructive for what they demonstrate not only about causal dynamics but also about prevention strategies (or lack thereof). Darfur and Rwanda are "negative" cases in that a concrete policy to stop the killing did not take shape in either episode. Analyzing the cases together offers some insight into why or why not. After Rwanda, analysts and activists gleaned certain lessons about how to generate an effective international response to genocide. Those lessons, in turn, shaped the social and activist response to Darfur. Yet the strategies that emerged around Darfur have not yet been successful in leading to a policy to halt the violence. Thus Darfur highlights dimensions that Rwanda did not, and comparing the cases offers insight that would not be evident if only one of the cases were considered in isolation.

\section{The Genocide Debate}

Darfur and Rwanda both show(ed) that terminology debates are central, and probably inevitable, when crises of such magnitude break out. In particular, whether to label each case one of "genocide" was (and continues to be, in the case of Darfur) a major point of discussion, though the outcomes differed. In the Rwandan case, powerful international actors chose not to use the word "genocide." US State Department spokespeople were told that they could only refer to "acts of genocide." That directive led to the now infamous exchange in which spokeswoman Christine Shelly was pressed on whether genocide was happening in Rwanda but would only acknowledge "acts of genocide." How many "acts of genocide" does it take to make genocide? she was asked. Shelly would not answer. ${ }^{32}$ 
The issue within the Clinton administration was that intervention was not a viable policy option. Less than a year after American soldiers were killed and dragged through the streets in Mogadishu, top American officials had no appetite for deploying troops in a risky situation in Central Africa. Nor did UN officials want to expose peacekeepers to increased risk after Somalia. ${ }^{33}$ The label "genocide" mattered because American officials worried that under the UNCG, which the US Senate had ratified, the United States would be obligated to act if the government formally recognized that genocide was occurring. Since forceful action was off the table, American officials did not want the term "genocide" used-despite overwhelming evidence that genocide was indeed occurring in Rwanda. Many observers concluded that the take-away lesson from Rwanda was that, even in the face of resistance to intervention, calling the violence "genocide" would trigger a forceful response.

Fast-forward to Darfur. In 2003, as the crisis unfolded, Darfur received little international attention. But 2004 was the tenth anniversary of the Rwandan genocide and the year that the violence in Darfur deepened. Both issues led to increased attention to Darfur. Given the experience of Rwanda a decade before, one focal point for activists was to pressure US officials to label the violence "genocide." During the summer of 2004, in particular, President George W. Bush came under pressure from an unusual coalition of actors to call Darfur "genocide." Congress passed a unanimous and historic declaration labeling the violence in Darfur "genocide." In response, Secretary of State Colin Powell hired an NGO, the Coalition for International Justice, to conduct a survey that would allow him to make a determination. That, NGO, in turn helped establish the Darfur Atrocities Documentation Team (ADT), which traveled to Chad and conducted an innovative survey of more than 1,100 Darfuri refugees. ${ }^{34}$

The results were convincing. The survey showed clearly that the violence was directed at black African Darfuris, that the government supported the violence, that the violence was widespread and organized, and that the aim was to destroy the population in substantial part. What was happening in Darfur was genocide. Powell subsequently appeared before a US Senate committee and declared that the term "genocide" applied to the violence in Darfur. The declaration was the first time a US administration official of such high ranking had conclusively declared genocide to be happening while the genocide was under way. Several weeks later, President Bush made the same claim in an address to the United Nations. ${ }^{35}$

However, the genocide declarations did not result in the kind of policy that many had hoped for. On this, Powell was clear: a formal genocide declaration would not lead to concrete policy changes on the part of the US government. Instead Powell brought the measure to the UN Security Council, which eventually created a commission to determine if, indeed, genocide was occurring. The resulting report by the UN Commission of Inquiry on Darfur documented the patterns of violence described by the Darfur ADT, as well as by other human-rights organizations and eyewitnesses. However, the commission concluded that "genocide" was not the right label because there was not conclusive evidence that Sudan's leaders intended to destroy the black African population in substantial part. The commission's report states that crimes against humanity had occurred-and that such crimes are as bad as genocide. ${ }^{36}$ The UN Security Council referred the matter to the International Criminal Court, which has subsequently begun investigating the crimes committed in Darfur. But more than a year later, a concrete policy has yet to be put in place to stop the violence, despite the historic determinations of genocide. 
What does all this show? First, the UNCG is not as powerful as some imagined. The convention holds that signatories are obligated to "prevent" genocide, but it lacks specific measures and mechanisms detailing how such prevention would work. In short, triggering the convention is not sufficient to provoke concrete international preventative action. There is thus a premium either on strengthening the convention, with a view toward making it more concrete, or on developing other protocols to trigger a forceful international response to massive violations of human rights (see below for more on the latter course).

Second, Darfur shows the risks of pushing too hard on a genocide determination. "Genocide" is a contested concept, one upon which reasonable people can disagree. Some people hold a broad view of genocide as large-scale mass violence directed against members of a particular social category, such as an ethnic or political group. Others hold a narrower view of genocide as extermination. ${ }^{37}$ The violence in Darfur is not a clear-cut case of intentional annihilation of an ethnic group, and hence some observers are uncomfortable using the label "genocide." Gérard Prunier, for example, calls Darfur an "ambiguous genocide" and a "quasi-genocide." 38 The UN Commission of Inquiry concluded that the term was not warranted. Other careful and thoughtful analysts reach the same conclusion. ${ }^{39}$ The point is that real differences do exist in defining "genocide," and Darfur shows that those differences will surface in the midst of crises and during situations that are not clear-cut cases of extermination. By extension, insisting too narrowly on using the label of "genocide" can, and in this case did, impede a policy discussion about how to halt the killing.

\section{Domestic Constituencies}

Darfur and Rwanda also provide an instructive contrast on domestic constituencies. In Rwanda, there was fairly little activism as the genocide unfolded. Human-rights organizations lobbied the Clinton administration and United Nations representatives, and many newspapers put Rwanda on their front pages, especially toward the end of the crisis. But there was no great public outcry to stop genocide in Rwanda. ${ }^{40}$ To be sure, the violence there was quick, and thus there was limited time to generate significant domestic pressure on the issue. Nonetheless, the lesson from Rwanda was that if activists expected political leaders to take risky and costly preventative actions, then they needed to lobby their representatives and to create domestic momentum. After reviewing various twentieth-century cases of genocide, Samantha Power concludes that "the battle to stop genocide has... been repeatedly lost in the realm of domestic politics." 11 For the battle to be won, argues Power, constituents, civil society, elite opinion makers, and bureaucrats within the government need to pressure representatives to create the necessary political will.

Darfur was different. In 2003, it is true, the violence received little international attention. But the situation changed in 2004 and 2005; in particular, in 2004, a UN official compared Darfur to Rwanda; ${ }^{42}$ the tenth anniversary of the events in Rwanda took place (and generated much interest and concern for Darfur); and the film Hotel Rwanda was released, giving considerable visibility to Rwanda and to genocide. Starting in 2004, a powerful and politically diverse informal coalition formed to pressure the Bush administration. That coalition included evangelical Christians, African Americans, human-rights organizations, Jewish-American groups, and government officials who were angered at what had happened in Rwanda a decade earlier. High-profile journalists, especially New York Times columnist Nicholas Kristof, wrote powerfully and doggedly about Darfur. There was also very vibrant 
student activism on Darfur on dozens of college and university campuses in the United States and Canada.

Rarely has there been such sustained, widespread, and politically eclectic domestic, civil-society activism on a foreign-policy issue, especially one that concerns Africa. African politics and issues only infrequently make editorial pages and only rarely become the subject of activist campaigns. Even then, particular issues remain salient only for short periods. Not so with Darfur: the pressure has been fairly consistent and persistent, even if the tsunami in December 2005 distracted attention from Darfur, at least for a while. US officials were responsive: domestic pressure resulted in the historic declarations of genocide, as we have seen. But the domestic pressure was not sufficient to generate a concrete policy to stop the genocide. Power may be right that the battle to halt genocide in the past has been lost in domestic politics, but it is also hard to imagine a more politically appealing and pervasive constituency forming on a human-rights issue in an African country. In short, Darfur shows that domestic pressure may be necessary, but it is not sufficient.

\section{Obstacles to Intervention}

In truth, there are many reasons why no intervention policy materialized. American troop commitments in Iraq and Afghanistan, as well as the course of the former war, made it politically difficult for US officials to deploy soldiers to an African country where they would have a strong moral purpose but lack a clear exit strategy. That being the case, a critical question is why other international actors did not take a leadership role on Darfur. Indeed, the battle to stop genocide in Darfur was lost less in domestic American politics than in the international arena. This, too, is a lesson from Darfur: international politics matter for developing a coherent and effective response to genocide.

Domestic constituents pressured American officials on Darfur, and American officials, in turn, brought the issue to the UN Security Council; it was there that the momentum to change policy on Darfur fizzled. American officials may be criticized for not doing more on Darfur, but it is clear that the American initiative ran into a phalanx of opposition at the Security Council. In particular, China and Russia initially blocked any serious resolution to punish Sudan through sanctions. In April 2006, however, China and Russia abstained on a US proposal to impose limited sanctions on both government forces and rebels. Still, there remains hostility to the idea of authorizing a military force to intervene in Darfur with a forceful mandate. China obtains a significant share of its oil from Sudan and has substantial investments there; Russia sells weapons to Sudan. Moreover, both countries are generally hostile to the idea that human-rights issues trump sovereignty. As two of the five permanent members of the Security Council, Russia and China acted as effective veto players when it came to harnessing the United Nations to take preventive action in Darfur.

Even beyond Russia and China, however, the issue of Darfur never gained much traction. In particular, Darfur did not capture the kind of public or political attention or concern in Europe that it did in the United States. Why Darfur never gained a head of steam in Europe is a story that remains to be written. Did Iraq cast a shadow over Darfur? That is, after Iraq, did the European public and political establishment distrust American leadership, especially concerning military action in an oilproducing, Arab-identified state? Or is the reason that the European Union is not an effective foreign-policy-making institution for dealing with crises outside Europe? The issue requires further investigation. Predictably, American officials encountered suspicion and opposition in the Arab world as they pressed for action on Darfur. The 
responses of African leaders were more mixed. In the end, the African Union deployed troops on a ceasefire-monitoring mission, but the troops' mandate was limited to protecting monitors and did not extend to protecting Darfuri civilians. The AU troops also lacked the resources, troop strength, and training to halt the violence. ${ }^{43}$

The issues underlying international paralysis in the face of genocide will not be easy to resolve. Despite widespread ratification of the UNCG, and despite repeated claims that halting massive abuses of human rights is a top priority of the United Nations, there remain deep divisions between states over the use of military force to stop genocide. The issue of sovereignty is particularly contentious when the intervening powers come from the West or the North and the subjects of intervention from the South, or less powerful states in general. There is clearly international suspicion that humanitarian intervention will be a mask for material and strategic interests. Powerful states may sidestep international disagreement when cases erupt near their borders. In 1999 in Kosovo, for example, American and Western European leaders employed NATO forces when Russia, China, and other countries blocked the Security Council from authorizing force. But for cases where less is at stake economically and strategically_those in Africa, for example-ignoring international opposition and sidestepping the United Nations become more difficult.

One way forward is to clarify international protocols for confronting genocide and for using military force to stop it. This would require renewed debate on the vexing questions surrounding humanitarian intervention. ${ }^{44}$ The "Responsibility to Protect" framework is a key initiative, one that received nominal backing at the 2005 UN summit in New York. But many concrete issues remain. Central to any policy will be determining a threshold for intervention, establishing clear mechanisms to identify the threshold, and clarifying international protocols for deploying the use of force once a threshold is met and other options are exhausted. Consensus on these issues remains distant, and it would be naïve to think that finding consensus will be easy. But Darfur shows that without resolution on some of these matters, there is little reason to expect a concrete and effective international response to genocide when it occurs.

The importance of international civic coalitions is another lesson from Darfur. American audiences took to heart the lessons from Rwanda, as we have seen. They were told that their representatives' phones needed to ring. Activists, in turn, developed a diverse coalition and successfully lobbied American legislators and the administration as the Darfur genocide unfolded. The effort was successful. But the international stage was where a policy to halt the violence in Darfur lost momentum. Clarifying international protocols to stop genocide will help, as I have argued, but so, too, will building an international coalition to prevent genocide.

In early May, as this issue was going to press, there were signs of progress. Responding to a new and intense round of lobbying, US officials initiated a major diplomatic effort to obtain a peace agreement between the Sudanese government and the Darfuri rebels. British, Canadian, and some African governments strongly supported the initiative. After days of intense negotiations, Sudanese government officials and the largest Darfuri rebel faction signed an agreement. Two rebel factions refused. The peace deal could lead to a lull in the violence and to a UN peacekeeping force in Darfur, though it is too early to know whether either will happen. But the diplomacy demonstrated the kind of coordinated and international effort required to make genocide prevention a reality. 


\section{Acknowledgments}

I would like to thank Eric Markusen and Samuel Totten, as well as two anonymous reviewers, for detailed comments on earlier drafts of this article.

\section{Notes}

1. Bureau of Intelligence and Research US Department of State, "Sudan: Death Toll in Darfur" (fact sheet, 25 March 2005), http://www.state.gov/s/inr/rls/fs/2005/45105.htm (accessed 24 April 2006); International Crisis Group, To Save Darfur (Brussels, 17 March 2006).

2. Coalition for International Justice, "New Analysis Claims Darfur Deaths Near 400,000" (Washington, DC, 21 April 2005); John Hagan, Wenona Rymond-Richmond, and Patricia Parker, "The Criminology of Genocide: The Death and Rape of Darfur," Criminology 43 (2005): 525-61.

3. Scott Straus, The Order of Genocide: Race, Power, and War in Rwanda (Ithaca, NY: Cornell University Press, 2006). Unless otherwise indicated, the analysis of the Rwandan genocide for this article is drawn from this source.

4. Alison Des Forges, Leave None to Tell the Story: Genocide in Rwanda (New York: Human Rights Watch, 1999).

5. Report of the International Commission of Inquiry on Darfur to the United Nations Secretary-General (25 January 2005), http://www.un.org/News/dh/sudan/com_inq_ darfur.pdf (accessed 19 April 2006) [COI Report]; Amnesty International, "Sudan, Darfur: Rape as a Weapon of War: Sexual Violence and Its Consequences" (AI Document AFR 54/ 076/2004, 19 July 2004); Human Rights Watch, Darfur Destroyed: Ethnic Cleansing by Government and Militia Forces in Western Sudan (New York: Human Rights Watch, 2004); Julie Flint and Alex de Waal, Darfur: A Short History of a Long War. (New York: Zed Books, 2005); Gérard Prunier, Darfur: The Ambiguous Genocide (Ithaca, NY: Cornell University Press, 2005).

6. CIIJ, "New Analysis."

7. COI Report; Flint and de Waal, Short History; Prunier, Darfur; US Department of State, Documenting Atrocities in Darfur (21 September 2004), http://www.state.gov/g/drl/rls/ 36028.htm (accessed 24 April 2006).

8. Flint and de Waal, Short History.

9. US State Department, Documenting Atrocities.

10. Flint and de Waal, Short History.

11. Human Rights Watch, Shattered Lives: Sexual Violence during the Rwandan Genocide and Its Aftermath (New York: Human Rights Watch, 1996), 13.

12. See Kelly Dawn Askin, "Holding Leaders Accountable in the International Criminal Court (ICC) for Gender Crimes Committed in Darfur," Genocide Studies and Prevention 1 (2006): $13-28$.

13. Flint and de Waal, Short History.

14. Ibid.; Prunier, Darfur.

15. Flint and de Waal, Short History, 38; Prunier, Darfur, 45.

16. Flint and de Waal, ibid., 7.

17. Ibid.; International Crisis Group, Darfur Rising: Sudan's New Crisis (Brussels, 25 March 2004); International Crisis Group, Darfur Deadline: A New International Action Plan (Brussels, 23 August 2004).

18. Flint and de Waal, Short History.

19. Ibid., 106.

20. Jean-Pierre Chrétien, The Great Lakes of Africa: Two Thousand Years of History, trans. Scott Straus (New York: Zone Books, 2003); Mahmood Mamdani, When Victims Become Killers: Colonialism, Nativism, and the Genocide in Rwanda (Princeton NJ: Princeton University Press, 2001). 
21. International Crisis Group, Sudan's Comprehensive Peace Agreement: The Long Road Ahead (31 March 2006); Prunier, Darfur.

22. Prunier, ibid.; Flint and de Waal, Short History.

23. Barbara Harff, "No Lessons Learned from the Holocaust? Assessing Risks of Genocide and Political Mass Murder since 1945," American Political Science Review 97 (2003): 57-73.

24. Rudolph Rummel, Death by Government (New Brunswick, NJ: Transaction, 1994).

25. Straus, Order of Genocide.

26. Manus Midlarsky, The Killing Trap: Genocide in the Twentieth Century (New York: Cambridge University Press, 2005); Martin Shaw, War and Genocide: Organized Killing in Modern Society (Oxford: Polity Press, 2003); Benjamin Valentino, Paul Huth, and Dylan Balch-Lindsay, "Draining the Sea': Mass Killing and Guerrilla Warfare," International Organization 58 (2004): 375-407.

27. Eric Weitz, A Century of Genocide: Utopias of Race and Nation (Princeton NJ: Princeton University Press, 2003); Jacques Sémelin, Purifier et détruire. Usages politiques des massacres et génocides (Paris: Seuil, 2005).

28. Prunier, Darfur.

29. Gérard Prunier, The Rwanda Crisis: History of a Genocide (New York: Columbia University Press, 1995).

30. Michael Mann, The Dark Side of Democracy: Explaining Ethnic Cleansing (New York: Cambridge University Press, 2004).

31. Leo Kuper, Genocide: Its Political Use in the 20th Century (New Haven CT: Yale University Press, 1981); Donald Horowitz, The Deadly Ethnic Riot (Berkeley and Los Angeles: University of California Press, 2001).

32. Samantha Power, "A Problem from Hell": America and the Age of Genocide (New York: Basic Books, 2002), 363-64.

33. Michael Barnett, Eyewitness to Genocide: The United Nations and Rwanda (Ithaca, NY: Cornell University Press, 2002).

34. Samuel Totten and Eric Markusen, "The U.S. Government Darfur Genocide Investigation," Journal of Genocide Research 7 (2005): 279-90; Samuel Totten and Eric Markusen, eds., Genocide in Darfur: Investigating the Atrocities in the Sudan (New York: Routledge, forthcoming).

35. Scott Straus, "Darfur and the Genocide Debate," Foreign Affairs 84 (2005): 123-33.

36. COI Report.

37. Scott Straus, "Contested Meanings and Conflicting Imperatives: A Conceptual Analysis of Genocide," Journal of Genocide Research 3 (2001): 349-75.

38. Prunier, Darfur, 90, 155-56.

39. Nelson Kasfir, "Sudan's Darfur: Is It Genocide?" Current History 104 (2005): 195-202.

40. Power, "A Problem from Hell."

41. Samantha Power, "Raising the Cost of Genocide," Dissent 49 (2002): 85-95, 91.

42. Prunier, Darfur, 114.

43. International Crisis Group, The AU's Mission in Darfur: Bridging the Gaps (Brussels, 6 July 2005); Prunier, Darfur, 144-46.

44. For overviews see J.L. Holzgrefe and Robert Keohane, eds., Humanitarian Intervention: Ethical, Legal, and Political Dilemmas (Cambridge: Cambridge University Press, 2003); Nicholas Wheeler, Saving Strangers: Humanitarian Intervention in International Society (Oxford: Oxford University Press, 2000). The Wisconsin International Law Journal plans to publish a special issue on the subject in summer 2006, with contributions from a number of leading scholars and practitioners. 


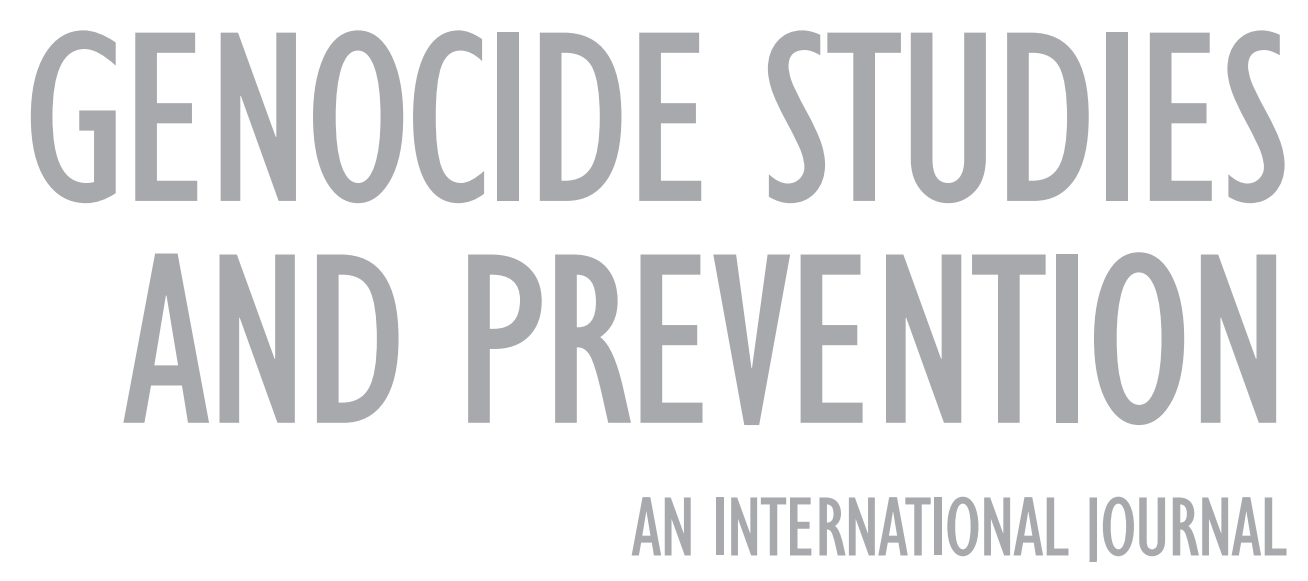

